\title{
Introducing research on recognition of prior learning
}

\author{
Per Andersson, Andreas Fejes and Fredrik Sandberg
}

\section{Linköping University Post Print}

\section{Tweet}

N.B.: When citing this work, cite the original article.

This is an electronic version of an article published in:

Per Andersson, Andreas Fejes and Fredrik Sandberg, Introducing research on recognition of prior learning, 2013, International Journal of Lifelong Education, (32), 4, 405-411.

International Journal of Lifelong Education is available online at informaworldTM:

http://dx.doi.org/10.1080/02601370.2013.778069

Copyright: Taylor \& Francis (Routledge)

http://www.routledge.com/

Postprint available at: Linköping University Electronic Press

http://urn.kb.se/resolve?urn=urn:nbn:se:liu:diva-95447 
Special issue title: Researching recognition of prior learning around the globe

\section{Introducing research on recognition of prior learning}

Per Andersson, Andreas Fejes, Fredrik Sandberg

Linköping University, Sweden

Recognition of prior learning (RPL) has emerged in recent decades as an important policy area and policy concept within the European Union, across countries in Europe and beyond. RPL is a phenomenon with a certain variation in practices as well as contexts, concepts and conceptions. However, there is a basic idea about giving recognition to prior learning wherever and whenever learning has taken place. Such ideas can be 'materialised' in formal assessment systems providing the basis for recognition, as well as in more non-formal and informal processes where prior learning is made visible and gets recognition.

The educational system is one central context of recognition of prior learning (RPL), where RPL can be the basis of admission as well as acceptance of credits or granting of advanced standing, particularly in secondary adult education and in tertiary education, including vocational education and training. Another central context is in working life, where varying practices of RPL are developing in employment services, in specific companies or by other employers, or in certain trades and industries. A third context where RPL is developing is the third sector, with a growing interest in identifying the value of learning taking place through (often voluntary and unpaid) work in this sector.

In this special issue, we use the concept RPL, but other concepts are applied too, and we do not make a distinction between these concepts here. For example, accreditation of prior 
experiential learning (APEL), prior learning assessment and recognition (PLAR) and validation of prior learning (VPL) are used as concepts in different countries, but here we see these different concepts rather as expressions of differences that depend on language and varying local development.

Nevertheless, there are also different conceptions of what RPL actually is. In other words, variations of, and departures from, the basic idea described above. These different conceptions mean that practitioners and researchers from different contexts could have somewhat different conceptions of what RPL is, and this should be kept in mind when reading the contributions in this issue. Further, researchers draw on different theories and methodologies that provide RPL with different meanings and interpretations.

The aim of this special issue on RPL is to provide a range of empirically and theoretically based contributions from different parts of the world where RPL, or an equivalent, is mobilised as part of educational practices for adults. Discussion in this area often takes place locally. This special issue brings together different kinds of contributions that hopefully will help create a broader dialogue among scholars and practitioners, not only on the specific topic of RPL, but also on more general issues faced in educational research. As Michael Young (2006, p. 326) puts it:

Questions about knowledge, authority, qualifications and different types of learning will always be with us. Once RPL is freed from its largely rhetorical role as the great radical strategy or the great solution to inequality, it offers a unique and very concrete set of contexts for debating the fundamental 
educational issues that such questions give rise to, and for finding new ways of approaching them.

\section{Discourses on lifelong learning and RPL}

The emergence of RPL or validation as a policy area is closely connected to discourses on lifelong learning. In Europe, lifelong learning first emerged clearly as a policy area with the Memorandum on Lifelong Learning, published by the European Commission (2001), which positions lifelong learning as a central policy concept in the realisation of the Commission's strategies. As a concept, lifelong learning partly replaces former concepts such as adult education (Lindeman, 1926), and lifelong education (Faure, 1972). Lifelong learning has become the dominant manner in which education and learning of adults is addressed in policy terms. The shift from focussing on education to speaking about learning signifies a shift that is important to address in research, because it marks a new way of conceptualising the adult learner in terms of, for instance, the how, what, when, where and output questions of learning.

The concept of lifelong education attained a central position on the policy level in the late 1960s and early 1970s. The catchword was, according to Rubenson (2004), personal development; people were to 'make themselves' instead of 'being made'. This concept was a humanistic definition of education produced through the Faure report, Learning to $B e$, published by UNESCO (Faure, 1972). In that report, lifelong education is related to a positive humanistic notion of progress and personal development. Faure saw personal development as good for society, and lifelong education would enable people to control and adapt to change (Fejes \& Nicoll, 2008; Rubenson, 2004). Similarly, from the early 1970s (see, e.g. Michelson, 1996), the concept of prior learning assessment (PLA) was introduced in the US in an effort to broaden access to higher education. The central idea was social justice. People who had not 
had the opportunity to enter higher education because of other commitments should be included in the admission system. For those groups, PLA thus became a way to access higher education. In RPL research, issues of social justice and social change have emerged as central. In practice, however, RPL has moved more and more from focusing on such aspects as social justice to a focus on the benefits to society, especially in economic development.

During the 1980s and 1990s, we can see such a shift in discourse, from a focus on social justice to a focus on economic development. For example, in the 1990s the concept of lifelong education was replaced by lifelong learning within the policy texts. UNESCO used lifelong learning in 1994 as a mid-term strategy for the coming years, and the OECD (1996) published the report Making Lifelong Learning a Reality for All. Lifelong learning also became a cornerstone in Jacques Delors's white paper on competitiveness and economic growth within the European Union in 1994. The European Commission then declared 1996 as the European Year of Lifelong Learning. In 2001, as noted above, the European Commission (2001) published their Memorandum on Lifelong Learning (The Lisbon Strategy), which positioned lifelong learning as a central policy concept in the realisation of the Commission's strategies, which had the goal of shaping Europe into a knowledge-based society. Policies on lifelong learning now came to produce an economic discourse, in which economic growth and employability were key issues (Fejes, 2010), rather than a humanist one (Fejes \& Dahlstedt, 2012; Rubenson, 2004). Similarly, the discourse on validation shifted. With developments of, for example, national qualification frameworks, and assessment of prior learning in relation to these frameworks (e.g. in the UK and Australia), the idea was to make it possible to use existing vocational/professional competence more effectively in the labour market. Clearly, the focus switched from social justice to economic development. Yet during the same period, recognition practices developed with a focus on social change. These practices were promoted 
mainly in post-apartheid South Africa, making the actual competence of the population visible in the process of creating better conditions for changing society (Andersson, Sjösten, \& Ahn, 2003).

Further shifts in discourses are visible when we focus on contemporary policy-making within the areas of lifelong learning and validation. For example, in 2010, the Lisbon Strategy was replaced by a new policy agenda called the Strategic Framework for Education and Training (European Commission, 2009). This agenda further outlined a long-term strategy for lifelong learning that included an initiative aiming to integrate work and education as a lifelong learning process in which validation would play a central role. A new discourse seems to emerge that includes both elements from the humanistic discourse of the 1970s and elements from the economic discourse of the 1980s. Whereas the discourse in the 1970s focused on human personal fulfilment, the focus is now on the 'personal, social and professional fulfilment of all citizens’ (European Commission, 2009, p. 2). Similarly, since the 1980s, the focus is now on 'sustainable economic prosperity and employability' (European Commission, 2009, p. 2), while 'promoting democratic values, social cohesion, active citizenship and intercultural dialogue’ (European Commission, 2009, p. 2). There is an assumption here, however, that personal, social and professional fulfilment go hand in hand. Despite borrowing elements from previous discourses, the aforementioned is a quite different discourse from the humanist one from the 1970s. The current discourse aims at shaping citizens who want to learn and who take responsibility for their own learning in order to become employable (Fejes, 2010).

In contemporary discourse, validation is positioned as a support in realising the idea of a knowledge-based society. As part of lifelong learning strategies, Member States are instructed 
to '[c]omplete the process of implementation of national lifelong learning strategies, paying particular attention to the validation of non-formal and informal learning and guidance' (European Commission, 2009, p. 8). Validation becomes a powerful tool in realising such a society. First, its insertion into the lifelong learning discourse, where, as mentioned above, a shift in focus has occurred from education to learning. The inclusion of non-formal and informal learning constructs learning as an all-embracing activity, no longer restricted only to educational settings. Learning here includes learning in and through venues such as the workplace, family life, leisure time, the media, crime prevention and health promotion. Thus, validation constructs life into a life of learning. Second, because validation positions all learning and all knowledge as valuable, citizens know that all they do and all they learn can be of formal value. As several of the contributions in this special issue argue, however, not all knowledge is awarded credits or valued in a formal sense. There are always discourses at play that position some knowledge and learning as valuable while excluding other forms of knowledge.

In conclusion, validation is today one of many proposed solutions to such problems as unemployment and low economic development. Drawing on what people already have learnt is expected to benefit both society and the individual. As has been described in this section, there are problems inherent in such reasoning. This special issue has as one of its aims to address critically contemporary discourses on RPL drawing on different theories and focussing on different local RPL practices across different countries. In the next section, we further position this special issue in relation to previous research on RPL. 


\section{RPL research and theory}

Much focus in RPL research has been on analysing different attempts to realise and implement RPL around the world, such as in Australia, Europe, South Africa, and the USA. A great deal of research has raised serious questions, especially in areas where more instrumental forms of RPL have been implemented, such as RPL for accreditation (e.g. Butterworth, 1992; Castle \& Attwood, 2001; Houston, Hoover, \& Beer, 1997; Spencer, 2005; Usher, 1989). At the same time, such research has had a rather practical focus, and more theoretical and scholarly research was for a long time rather limited. It was not until recent years that theorisations of RPL have become more frequent (e.g. Andersson \& Harris, 2006; Harris, Breier, \& Wihak, 2011; Sandberg, 2012a, 2012b).

There are some contexts and approaches that has been of specific interest for researchers in RPL, such as RPL in nursing programs (Heath, 2001; Houston et al., 1997; Howard, 1993; Murray, 1994; Scott, 2007), the health care sector (Fearfull, 1997, 1998; Fejes, 2011, 2012; Fejes \& Andersson, 2009; Hamer, 2010; Hartley, 2000; Sandberg, 2012a, 2012b), higher education (Castle \& Attwood, 2001; Sandberg \& Andersson, 2011), different forms of RPL for accreditation (Briton, Gereluk, \& Spencer 1998; Heath, 2001; Howard, 1993; Houston et al., 1995; Michelson, 1996; Murray, 1994; Peters, 2005; Sandberg, 2012a; Scott, 2007, 2010; Spencer, 2005a; Taylor 1996; Wheelahan, 2006), and RPL and its connection to learning (Breier, 2005), for instance, its integration in education programmes (Brown, 2001, 2002).

Certainly, this special issue has a particular focus on how RPL has been, and can be, theorised. Even though theoretical studies of RPL are limited, some attempts can be summarised and discussed further. Theoretically, the model of experiential learning developed by Kolb (1984) can be seen a kind of ideological-theoretical base for much 
research on RPL. This 'Kolbianism’ (e.g. Sandberg, 2012a), together with its focus on experiential learning philosophies, has become a problem because it seems to restrict the possibility of analysing RPL from other theoretical perspectives. As argued by Andersson and Harris (2006), RPL research seems to dawdle behind developments in social and educational theory. As was proposed above, however, a progression towards more theoretical studies has emerged, and this special issue is an attempt to encourage such an important trend.

If we examine RPL research with a more theoretical focus, a variety, with different epistemological premises, can be delineated. For instance scholars and perspectives drawn upon include: poststructuralism (Andersson \& Osman, 2008; Fejes, 2008, 2012); critical social theory, for instance, Jürgen Habermas (Houlbrook, 2012, Sandberg, 2010, 2012a, 2012b; Sandberg \& Andersson, 2011), Axel Honneth (Hamer, 2012; Sandberg 2012a; Sandberg \& Kubiak, 2013), and Pierre Bourdieu (Cooper, 2011); sociology of translation (Diedrich, 2012); transformative learning (Stevens, Gerber, \& Hendra, 2010); socio-cultural theory (Andersson \& Hellberg, 2009); and a constructivist perspective (Fejes \& Andersson, 2009).

Based on such theorisations a more critical analysis and in-depth understanding of RPL has been made possible. More theoretical analysis has and will continue to shed further light on such issues as power, gender and ethnicity, as well as produce a more scholarly analysis of the different epistemological characters of RPL.

The articles in this special issue are expressions of the present research on RPL, a research field that is developing in different parts of the world, in different disciplines, and with a number of different theoretical starting points. A number of initiatives have been taken to 
bring together and make prior RPL research visible, some of which will be mentioned here. Two edited collections have been published by NIACE in recent years. Andersson and Harris (2006) bring together and present a number of different theoretical approaches that have been employed to theorise RPL. Harris et al. (2011) take a further step and present overviews of RPL research in different parts of the world. Numerous journal articles have been published, but most often, individually in different journals. However, in 2012, a special issue was published in the Journal of Workplace Learning, particularly focusing on the work-life context of RPL. In 2012, there was also a new online journal launched, PLAIO, 'Prior Learning Assessment Inside Out: An International Journal on Theory, Research and Practice in Prior Learning Assessment', which is dedicated to RPL (or in this case, PLA).

\section{Concluding remarks}

This issue includes nine articles that build on empirical studies in varying contexts drawing on different theoretical concepts. Taken together, we hope that these articles will provide new insights into the challenges and opportunities of RPL practices and, particularly, insight into RPL research where theoretical concepts are guiding the analysis of empirical material. Theoretical analysis takes our understanding of RPL to a much deeper level, and as Young stated in the introduction, it is when we free RPL from its rhetorical roles it can offer exclusive contexts for a debate of fundamental, but also contemporary, issues in education.

\section{References}

Andersson, P., \& Harris, J. (Eds.). (2006). Re-theorising the recognition of prior learning. Leicester: NIACE.

Andersson, P., \& Hellberg, K. (2009). Trajectories in teacher education: Recognising prior learning in practice. Asia-Pacific Journal of Teacher Education, 37(3), 271-282. 
Andersson, P., \& Osman, A. (2008). Recognition of prior learning as a practice for differential inclusion and exclusion of immigrants in Sweden. Adult Education Quarterly, 59(1), 42-60.

Andersson, P., Sjösten, N-Å., \& Ahn, S-E. (2003). Att värdera kunskap, erfarenhet och kompetens. Perspektiv på validering [To value knowledge, experience and competence. Perspectives on validation], Forskning i fokus, nr 9. Stockholm: Myndigheten för skolutveckling.

Breier, M. (2005). A disciplinary-specific approach to the recognition of prior informal experience in adult pedagogy: 'rpl' as opposed to 'RPL'. Studies in Continuing Education, 27(1), 51-65.

Briton, D., Gereluk, W., \& Spencer, B. (1998). Prior learning assessment and recognition: Issues for adult educators. Paper presented at the CASAE Conference Proceedings, University of Ottawa Ontario, Canada.

Brown, J. O. (2001). The portfolio: A reflective bridge connecting the learner, higher education and the workplace. The Journal of Continuing Higher Education, 49(2), 113.

Brown, J. O. (2002). Know thyself: The impact of portfolio development on adult learning. Adult Education Quarterly, 52(3), 228-245.

Butterworth, C. (1992). More than one bite at the APEL. Journal of Further and Higher Education, 16(3), 39-51.

Castle, J., \& Attwood, G. (2001). Recognition of prior learning (RPL) for access or credit? Problematic issues in a university adult education department in South Africa. Studies in the Education of Adults, 33(1), 60-71.

Cooper, L. (2011). Activists within the academy: The role of prior experience in adult learners’ acquisition of postgraduate literacies in a postapartheid South African 
university. Adult Education Quarterly, 61(1), 40-56.

Diedrich, A. (2012). "Who's giving us the answers?" Interpreters and the validation of prior foreign learning. International Journal of Lifelong Education,

DOI:10.1080/02601370.2012.733975

European Commission. (2001). Communication from the Commission: Making a European Area of Lifelong Learning a Reality. Brussels: European Commission, Directorate-general for Education and Culture and Directorate-general for Employment and Social Affairs.

European Commission. (2009). Strategic framework for European cooperation in Education and training. Notices from European Union Institutions and Bodies: Official Journal of the European Union, Council Conclusions 2009. Brussels: European Commission.

Faure, E. (1972). Learning to Be. Paris: UNESCO.

Fearfull, A. (1997). Training, vocational qualifications and employee performance in care work in the UK. International Journal of Training and Development, 1(3), 158-172.

Fearfull, A. (1998). 'It's just like somebody’s turned on a light': an NVQ success story from the voluntary sector. Manpower Management, 24(1), 13-19.

Fejes, A. (2008). Governing nursing through reflection: a discourse analysis of reflective practices. Journal of Advanced Nursing, 64(3), 243-250.

Fejes, A. (2010). Discourses on employability: Constituting the responsible citizen. Studies in Continuing Education, 32(2), 89-102.

Fejes, A. (2011). Confession, in-service training and reflective practices. British Educational Research Journal, 37(5), 797-812.

Fejes, A. (2012). Knowledge at play: Positioning care workers as professional through scientific rationality and caring dispositions. In A. Kamp \& H. Hvid (Eds.), Elderly care in transition - management, meaning and identity at work: A Scandinavian perspective (pp. 83-105). Copenhagen: Copenhagen Business School Press. 
Fejes, A., \& Andersson, P. (2009). Recognising prior learning: Understanding the relations among experience, learning and recognition from a constructivist perspective. Vocations and Learning, 2(1), 37-55.

Fejes, A., \& Dahlstedt, M. (2012). The confessing society: Foucault, confession and practices of lifelong learning. London: Routledge.

Fejes, A., \& Nicoll, K. (Eds.). (2008). Foucault and lifelong learning: Governing the subject. London: Routledge.

Hamer, J. (2010). Recognition of prior learning - normative assessment or co-construction of preferred identities? Australian Journal of Adult Learning, 50, 100-115.

Hamer, J. (2012). An ontology of RPL: Improving non-traditional learners' access to the recognition of prior learning through a philosophy of recognition. Studies in Continuing Education, 34, 113-127.

Harris, J., Breier, M., \& Wihak, C. (Eds.). (2011). Researching the recognition of prior learning: International perspectives. Leicester: NIACE.

Hartley, R. (2000). Area health services as learning organisations: The rural experience. Australian Journal of Rural Health, 8, 77-80.

Heath, V. (2001). Accreditation of prior (experiential) learning: Making the difference. Nurse Education Today, 21, 496-500.

Houlbrook, M.C. (2012). RPL practice and student disposition - insights from the lifeworld. Journal of Education and Work, 25, 555-570.

Houston, Y.L, Hoover, J., \& Beer, E. (1997). Accreditation of prior learning: Is it worth it? An evaluation of a pilot scheme. Nurse Education Today, 17, 184-191.

Howard, S. (1993). Accreditation of prior learning: Andragogy in action or a 'cut price' approach to education? Journal of Advanced Nursing, 18, 1817-1824.

Journal of Workplace Learning, 24(2), (2012). Special Issue on RPL entitled 'Learning 
through Experience: Developing Synergies between Research and Practice in Workplace Learning, Work-based Learning and the Recognition of Prior Learning'.

Lindeman, E.C. (1926). The Meaning of Adult Education. New York: New Republic.

Michelson, E. (1996) Beyond Galileo’s telescope: Situated knowledge and the assessment of experiential learning. Adult Education Quarterly, 46(4), 185-196.

OECD. (1996). Lifelong Learning for All. Paris: OECD.

Peters, H. (2005). Contested discourses: Assessing the outcomes of learning from experience for the award of credit in higher education. Assessment and Evaluation in Higher Education, 30(3), 273-285.

PLAIO, Prior Learning Assessment Inside Out: An International Journal on Theory, Research and Practice in Prior Learning Assessment. www.plaio.org

Rubenson, K. (2004). Lifelong learning: A critical assessment of the political project. In P. Alheit, R. Becker-Schmidt, T. Gitz-Johansen, L. Ploug, H. Salling Olesen, \& K. Rubenson (Eds.), Shaping an Emerging Reality - Researching Lifelong Learning. Roskilde: Roskilde University Press.

Sandberg, F. (2010). Recognising health care assistants' prior learning through a caring ideology. Vocations and learning, 3(2), 99-115.

Sandberg, F. (2012a). Recognition of prior learning in health care: From a caring ideology and power, to communicative action and recognition. Linköping: Linköping University. Sandberg, F. (2012b). A Habermasian analysis of a process of recognition of prior learning for health care assistants. Adult Education Quarterly, 62, 351-370.

Sandberg, F., \& Andersson, P. (2011). RPL for accreditation in higher education: As a process of mutual understanding or merely lifeworld colonisation? Assessment and Evaluation in Higher Education, 36, 767-780. 
Sandberg, F., \& Kubiak, C. (2013). Recognition of prior learning, self-realisation and identity within Axel Honneth's theory of recognition. Studies in Continuing Education, doi: 10.1080/0158037X.2013.768230

Scott, I. (2007). Accreditation of prior learning in pre-registration nursing programmes: Throwing out the baby with the bath water? Nurse Education Today, 27, 348-356.

Scott, I. (2010). Accreditation of prior learning in pre-registration nursing programmes 2: The influence of prior qualifications on perceived learning during the foundation year. Nurse Education Today, 30, 438-442.

Somerville, M. (2006). Becoming-worker: vocational training for workers in aged care. Journal of Vocational Education and Training, 54(4), 471-481.

Spencer, B. (2005). Defining prior learning assessment and recognition. In L. English (Ed.). Encyclopaedia of adult education. Basingstoke: Palgrave Macmillan.

Stevens, K., Gerber, D., \& Hendra, R. (2010). Transformational Learning Through Prior Learning Assessment. Adult Education Quarterly, 60(4), 377-404.

Taylor, T. (1996). Learning from experience: Recognition of prior learning (RPL) and professional development for teachers. Asia-Pacific Journal of Teacher Education, 24, 281-292.

Usher, R. (1989). Qualifications, paradigms and experiential learning in higher education. In O. Fulton (Ed.), Access and Institutional Change (pp. 64-81) London: SRHE/OUP.

Wheelahan, L. (2006). Vocations, 'graduateness' and the recognition of prior learning. In P. Andersson \& J. Harris (Eds.), Re-theorising the Recognition of Prior Learning (pp. 241-260). Leicester: NIACE.

Young, M. (2006). Endword. In P. Andersson \& J. Harris (Eds.) Re-theorising the Recognition of Prior Learning (pp. 321-326). Leicester: NIACE. 